\title{
Peran Perawat Dalam Meningkatkan Keselematan Pasien Dirumah Sakit
}

\author{
Intan Faadhilah (191101053)
}

\section{Intanfaadhilah24@gmail.com}

\section{Latar Belakang}

\begin{abstract}
Keselamatan pasien atau patient safety merupakan sistem pelayanan rumah sakit yang memberikan asuhan pasien secara lebih aman. Termasuk didalamnya prosedur : mengukur (assessing) risiko, identifikasi, dan pengelolaan risiko terhadap pasien, pelaporan dan analisis insiden, kemampuan untuk menindaklanjuti insiden serta menerapkan solusi untuk mengurangi serta meminimalisasi risiko yang juga melalui komunikasi dengan pasien. Dapat dikatakan bahwa fokus utama patient safety adalah upaya yang dilakukan untuk menghindari terjadinya kesalahan.(1) WHO
\end{abstract} mengestimasikan, 1 dari 10 pasien dirugikan selama mendapatkan pelayanan kesehatan di rumah sakit yang terjadi di negara-negara maju. Sedangkan di negara-negara berkembang, peluang pasien untuk dirugikan selama menerima perawatan kesehatan di rumah sakit lebih tinggi dibandingkan negara-negara industri. Risiko kejadian infeksi dalam pelayanan kesehatan di negaranegara berkembang 20 kali lebih besar dibandingkan negaranegara maju.(2) Masalah kesehatan terkait patient safety pun kerap dikeluhkan di Indonesia. Departemen Kesehatan Republik Indonesia menyatakan bahwa data KTD, terlebih pada Kejadian Nyaris Cedera (Near Miss) masih sangat langka dalam pelaporan, namun terjadi peningkatan tuduhan terhadap malpraktik. Jika dibandingkan dengan negara-negara maju seperti Amerika dan Inggris yang memiliki standar pelayanan kesehatan lebih baik dari Indonesia, dapat dibayangkan angka KTD dan kesalahan medis yang terjadi di Indonesia dapat lebih besar pula.(3) Pelayanan gawat darurat merupakan salah satu komponen pelayanan rumah sakit yang dilaksanakan di Instalasi Gawat Darurat (IGD). Adapun fungsi IGD adalah menyelenggarakan pelayanan asuhan medis dan asuhan keperawatan serta pelayanan pembedahan darurat bagi pasien yang datang dengan gawat darurat medis. Sebagai unit pelayanan yang menanggulangi penderita gawat darurat, IGD merupakan high clinical 
risks areas, oleh karena itu pelayanan di IGD harus dikelola sedemikian rupa sehingga pasien mendapatkan perawatan yang baik dan aman, salah satu upaya untuk mewujudkan pelayanan yang aman adalah kembali lagi dengan penerapan patient safety yang baik di IGD.(4) Belum terdapat data mengenai kejadian terkait keselamatan pasien (patient safety) di IGD yang lengkap dan akurat di Indonesia, namun berdasarkan data Komite Keselamatan Pasien Rumah Sakit.

\section{Tujuan}

Mengidentifikasi atau mendiagnosa pasien dengan benar Maksud dari sasaran ini adalah untuk melakukan dua kali pengecekan, yaitu: pertama, untuk identifikasi pasien sebagai individu yang akan menerima pelayanan atau pengobatan; dan kedua, untuk kesesuaian pelayanan atau pengobatan terhadap individu tersebut.Meningkatkan komunikasi secara efektif Komunikasi efektif, yang tepat waktu, akurat, lengkap, jelas dan yang dapat dipahami oleh pasien akan mengurangi kesalahan, dan menghasilkan peningkatan keselamatan pasien. Meningkatkan keamanan dari high-alert medication Obatobatan yang perlu diwaspadai (high-alert medications) merupakan obat yang sering menyebabkan kesalahan atau kesalahan serius. Kesalahan dapat terjadi bila perawat tidak mendapatkan orientasi yang baik dan dalam situasi darurat. Memastikan benar tempat, benar prosedur dan benar pembedahan pasien Salah lokasi, salah prosedur, pasiensalah pada operasi, adalah sesuatu yang sangat mengkhawatirkan dan tidak jarang terjadi di rumah sakit. Mengurangi infeksi dari pekerja kesehatan Infeksi biasanya dijumpai dalam semua bentuk pelayanan kesehatan termasuk infeksi saluran kemih, infeksi pada aliran darah (bloodstream infections) dan pneumonia (sering kali dihubungkan dengan ventilasi mekanis). Mengurangi terjadinya risiko jatuh pada pasien Jumlah kasus jatuh pada pasien cukup bermakna sebagai penyebab cedera bagi pasien rawat inap. Dalam konteks populasi/masyarakat yang dilayani, pelayanan yang disediakan, dan fasilitasnya, rumah sakit perlu mengevaluasi risiko pasien jatuh dan mengambil tindakan untuk mengurangi risiko cedera bila sampai jatuh. Perlunya keselamatan pasien (patient safety) diterapkan pada tindakan medis, dikarenakan kompleksnya rangkaian tindakan medis yang kerap dilakukan. Dimulai dengan diagnosa, pertolongan pertama, pemeriksaan laboratorium, pemberian obat hingga 
tindakan pembedahan yang memungkinkan terjadinya kesalahan-kesalahan medis.

\section{Metode}

Jurnal ini menggunakan metode tersearch dan analisis dari berbagai sumber seperti buku teks, buku referensi jurnal, ebook, dan juga membandingkan beberapa jurnal yang berhubungan dengan peran perawat dalam pelayan keselamatan pasien . Dari analisi berbagai sumber digunakan Untuk mengetahui bagai mana peran perawat dalam melakukan pelayanan keselamatan pasien. Penulisan jurnal ini dimulai pada tanggal 01 oktober 2019. Pengolahan jurnal dilakukan dengan metode membandingkan beberapa jurnal yang berhubungan peran pearawat dalam melakukan pelayanan keselamatan pasien.

\section{Hasil}

Berdasarkan hasil penelitian dari (Jurnal IKESMA Volume 11 Nomor 1 Maret 2015) terhadap indikator budaya keselamatan yang meliputi kerja sama, komunikasi, kepemimpinan, pelaporan dan respon tidak menghukum terhadap kesalahan didapatkan hasil dan pembahasan sebagai berikut : 1 . Kerjasama Kerjasama merupakan indikator pertama dari budaya keselamatan pasien. Berdasarkan hasil dari penelitian, 73 responden atau sebesar $64,6 \%$ dari sampel yang dipilih (113 perawat) dalam melaksanakan asuhan keperawatan selalu bekerja sama dengan sesama perawat maupun dengan tenaga kesehatan lainnya dengan baik. 2. Komunikasi Berdasarkan hasilpenelitian untuk indikator budaya komunikasi didapatkan 61 responden $(54,0 \%)$ dari 113 responden telah melakukan budaya komunikasi. 3. Kepemimpinan Berdasarkan hasil penelitian untuk variabel kepemimpinan, dalam hal ini partisipasi pemimpin di semua ruang rawat inap Rumah Sakit X Kabupaten Jember untuk mendukung keselamatan pasien adalah dalam kategori baik, hal ini didukung oleh hasil penelitian yang sebesar 91,2 \% atau sebanyak 103 responden menyatakan hal tersebut. 4. Pelaporan Indikator pelaporan dalam penerapan budaya keselamatan pasien berada dalam kategori cukup. Hal ini didukung oleh hasil penelitian yang menunjukkan bahwa 70 responden $(61,9 \%)$ yang menyatakan hal tersebut. 5. Respon Tidak Menghukum Terhadap Kesalahan Seiring dengan hasil indikator pelaporan pada insiden keselamatan pasien, hasil penelitian untuk indikator respon tidak menghukum terhadap kesalahan juga berada dalam kategori cukup. Hal ini ditunjukkan oleh hasil penelitian sebesar 51, $3 \%$ atau sebanyak 58 dari 113 responden 
menyatakan cukup. Dari peneliti jurnal (Syarianingsih Syam, nur. Implementasi Budaya Keselamatan Pasien oleh Perawat di Rumah Sakit Ibnu Sina Makasar. Kes Mas: Jurnal Fakultas Kesehatan Masyarakat, Universitas Ahmad Dahlan, Yogyakarta, IndonesiaVolume 11, Issue 2, September 2017, pp. $169 \sim 174$ ISSN: 1978 - 0575) mengatakan bahwa, Tantangan terbesar yang perlu dilakukan dalam menciptakan budaya keselamatan pasien yang terbuka adalah mendirikan dan mempertahankan budaya positif tentang keselamatan pasien pada organisasi pelayanan kesehatan. Karakteristik budaya positif tentang keselamatan pasien di antaranya adalah persepsi yang diinformasikan tentang pentingnya keselamatan pasien, dan komitmen pemimpin serta tanggung jawab pembuat kebijakan. Scott menyatakan bahwa pengembangan budaya positif keselamatan pasien dapat meningkatkan kinerja karyawan dalam menerapkan program keselamatan pasien. Salah satu tenaga yang berperan dalam usaha peningkatan budaya keselamatan pasien adalah perawat. Perawat melaksanakan tugas 24 jam dalam tujuh hari pelayanan langsung kepada pasien. Pelayanan yang diberikan berupa perawatan langsung dan pemeriksaan keadaan klinis pasien. Selain hal tersebut perawat juga melakukan koordinasi dan integrasi layanan perawatan lintas profesi dan unit.

\section{Pembahasan}

Dari hasil peneliti jurnal (Vena Jaladara, dkk. Hubungan tingkat pengetahuan dan praktik perawat mengenai keselamatan pasien (patient safety) di instalasi gawat darurat rs $\mathrm{x}$ semarang. Jurnal kesehatan masyarakat. (e-Journal) Volume 3, Nomor 1, Januari 2015 (ISSN: 2356-3346) http://ejournals1.undip.ac.id/index.php/jk m ). Keselamatan pasien (patient safety) rumah sakit merupakan suatu sistem dimana rumah sakit membuat pelayanan pasien menjadi lebih aman. Sistem tersebut meliputi penilaian risiko, identifikasi dan pengelolaan hal yang berhubungan dengan risiko pasien, pelaporan dan analisis insiden, kemampuan belajar dari insiden dan tindak lanjutnya serta implementasi solusi untuk meminimalisasi timbulnya risiko. Sistem tersebut diharapkan dapat mencegah terjadinya cedera yang disebabkan oleh suatu tindakan yang dilakukan atau tidak melakukan suatu tindakan yang seharusnya dilakukan. Berdasarkan dari hasil peneliti (Jurnal IKESMA Volume 11 Nomor 1 Maret 2015) indikator budaya keselamatan yang meliputi pelayanan keselamatan pasien yaitu: 1. Kerjasama Kerjasama merupakan indikator 
pertama dari budaya keselamatan pasien. Berdasarkan hasil dari penelitian, dalam melaksanakan asuhan keperawatan kepada pasien perawat akan selalu membutuhkan bantuan dari perawat maupun tenaga kesehatan yang lainnya.. banyak profesi selain tenaga perawat dalam melakukan asuhan keperawatan dapat menimbulkan atau berisiko terjadi cidera jika dilakukan tidak dengan komunikasi dan koordinasi yang tepat3, hal itu (cidera) dapat dihindari jika perawat selalu menjaga hubungan baik dengan sesama perawat dan petugas kesehatan lainnya, dan menjaga keharmonisan di lingkungan kerja atau suasana hati untuk mencapai pelayanan kesehatan. 2. Komunikasi Komunikasi sangatlah penting dalam setiap melaksanakan tugas dalam hal ini adalah melaksanakan asuhan keperawatan pada pasien. Komunikasi yang baik dan benar perlu dilakukan untuk mengkoordinasikan asuhan keperawatan yang melibatkan banyak profesi selain profesi perawat. Komuniasi dalam praktek keperawatan merupakan elemen penting bagi perawat dalam melaksanakan asuhan keperawatan untuk mendapatkan hasil yang optimal. Perawat memiliki peran yang paling dominan dalam mencegah terjadinya kesalahan dalam pengobatan, termasuk pelaporan insiden, mendidik diri sendiri dan perawat lain tentang penting komunikasi, memberikan rekomendasi untuk perubahan prosedur dan kebijakan serta keterlibatan dalam melakukan identifikasi permasalahan. 3. Kepemimpinan Pemimpin harus memiliki komitmen yang kuat terhadap keselamatan pasien, sehingga keselamatan pasien menjadi hal yang utama dalam memberikan pelayanan keperawatan. Pemimpin harus mampu menjadi agen perubahan bagi anak buahnya dengan melaksanakan program keselamatan pasien. Pimpinan mendorong dan menjamin implementasi program keselamatan pasien secara terintegrasi dalam organisasi melalui penerapan "Tujuh Langkah Menuju Keselamatan Pasien Rumah Sakit”. Pemimpin harus membangun komitmen dan fokus yang kuat dan jelas guna mendukung staff untuk menjalankan program keselamatan pasien secara berkesinambungan, memprioritaskan atau mengintegrasikan program keselamatan pasien dalam setiap rapat dengan para pengambil keputusan, mengagendakan pelatihan tentang keselamatan pasien bagi semua staf secara berkala dan berkesinambungan. Pimpinan menjamin berlangsungnya program proaktif untuk identifikasi risiko keselamatan pasien dan program menekan atau mengurangi Kejadian 
Tidak Diharapkan. Pimpinan mendorong dan menumbuhkan komunikasi dan koordinasi antar unit dan individu berkaitan dengan pengambilan keputusan tentang keselamatan pasien. 4. Pelaporan Indikator pelaporan dalam penerapan budaya keselamatan pasien berada dalam kategori cukup. Perawat diharuskan melaporkan kejadian kesalahan yang tidak disengaja dan kondisi yang mengakibatkan atau berpotensi mengakibatkan cedera yang dapat dicegah pada pasien, yang terdiri dari kejadian tidak diharapkan, kejadian nyaris cedera, kejadian tidak cedera dan kejadian potensial cedera. Melaporkan sebuah kejadian atau insiden keselamatan pasien masih jarang dilakukan atau pun bahkan jika ada pelaporan tentang insiden atau kejadian keselamatan pasien belum ada pelaporan secara resmi. Hal ini disebabkan para perawat takut untuk melaporkan insiden yang terjadi pada pasien karena kesalahan yang dilakukannya. Perawat merasa takut akan hukuman dari penyelia atas kesalahan yang telah ia lakukan saat melakukan asuhan keperawatan. 5. Respon Tidak Menghukum Terhadap Kesalahan. Indikator respon tidak menghukum terhadap kesalahan ini menunjukkan bahwa dimasa yang akan datang pelaporan terhadap insiden keselamatan pasien tidak semata-mata hanya berupa pelaporan insiden keselamatan, namun pelaporan tersebut hendaknya ditindaklanjuti guna memperbaiki kesalahan dan mencari akar permasalahan, tidak untuk menghukum perawat yang melakukan kesalahan atau berpengaruh terhadap penilainan kinerjanya. Ketika kesalahan dilaporkan, maka cukup melaporkan masalah sendiri dilaporkan menemukan jalan keluar tidak menunjukkan siapa pelaku harus dihukum. Belajar dari insiden keselamatan pasien hanya akan berhasil jika setiap permasalahan tidak dilihat sebagai kesalahan individu tetapi harus diperhatikan dengan pendekatan sistem dan pemahaman faktor manusia. Sebagaimana diatur dalam Peraturan Menteri Kesehatan Republik Indonesia nomer 755/Menkes/Per/IV/2011 tentang pelaksanaan komite medis di rumah sakit bahwa audit medis dilakukan dengan memprioritaskan semua staf untuk menghilangkan blaming (menyalahkan), naming (menyebut atau mencari siapa yang salah), dan shaming (mempermalukan atau mengakui kesalahan). Standar pelayanan kesehatan di Indonesia masih kurang optimal jika dibandingkan dengan negara maju seperti Amerika dan Inggris. Hughes menyatakan bahwa langkah awal untuk memperbaiki pelayanan yang berkualitas adalah keselamatan, sedangkan kunci dari 
pelayanan yang bermutu dan aman adalah membangun budaya keselamatan pasien. Di Indonesia sendiri upaya untuk menurunkan angka KTD dan KNC adalah dengan mencanangkan "Gerakan Keselamatan Pasien di Rumah Sakit". Gerakan ini baru dicanangkan pada tahun 2005 silam, namun hingga kini penerapannya belum komprehensif. Di rumah sakit salah satu tenaga yang berperan dalam meningkatkan keselamatan pasien adalah perawat. Keselamatan pasien bagi perawat tidak hanya merupakan pedoman tentang apa yang seharusnya dilakukan, namun keselamatan pasien merupakan komitmen yang tertuang dalam kode etik perawat dalam memberikan pelayanan yang aman, sesuai kompetensi, dan berlandaskan kode etik bagi pasien. Luasnya peran perawat memungkinkannya untuk menemukan dan mengalami risiko kesalahan pelayanan. Temuan kesalahan pelayanan hanya akan dilaporkan jika si

Asmuji; Manajemen Keperawatan

(Konsep dan Aplikasi),

Jogjakarta 2014.

Asmuji; Manajemen Keperawatan

(Konsep dan Aplikasi),

Jogjakarta 2014. perawat merasa aman dan mendapat pelakuan terbuka dan adil.

\section{Kesimpulan}

Dari beberapa hasil penelitian jurnal mengatakan bahwa, Salah satu tenaga yang berperan dalam usaha peningkatan budaya keselamatan pasien adalah perawat. Peran perawat dalam mengimplementasikan asuhan keperawatan dan mewujudkan keselamatan pasien di rumah sakit dapat dirumuskan sebagai berikut, perawat harus mematuhi standar layanan dan SOP yang telah ditetapkan, menerapkan prisip etik dalam meberikan asuhan keperawatan, memberikan pendidikan kepada pasien dan keluarga pasien tentang asuhan keperawatan yang sedang dijalankan, oleh karena itu, Peran perawat terhadap pelayanan keselamatan pasien sangat berperan penting untuk keselamatan pasien

\section{Referensi}

Kusumapraja, R. 2011. Perencanaan

Kebutuhan Tenaga Perawat di

RS. MakalahManajemen

Keperawatan. RSU Persahabatan.

Jakarta.

Komite Keselamatan Pasien Rumah Sakit 
(KKP-RS). Laporan Insiden

Keselamatan Pasien. Jakarta:

Kementerian Kesehatan Republik

Indonesia; 2011.

Komite Keselamapatan Pasien Rumah

Sakit. Laporan Insiden

Keselamatan Pasien Periode :

September-Desember 2010. 2010

(Online)(http://www.inapatsafety

persi.or.id/?show=data/triwulan3

2010/lap_ikp32 010) diakses

pada tanggal 27 September 2014

pukul 19.37 WIB

Menteri Kesehatan Indonesia. Peraturan

Menteri Kesehatan Indonesia

Nomor1691/MENKES/PER/VIII

/2011 Tentang Keselamatan

Pasien Rumah Sakit. Departemen

Kesehatan Republik Indonesia.

2011

Nursalam; Manajemen Keperawatan

(Aplikasi dalam Praktik

Keperawatan Profesional) edisi 4,
Jakarta 2014.

Notoatmodjo, Soekidjo. Promosi

Kesehatan dan Perilaku

Kesehatan Edisi Revisi 2012.

Rineka Cipta. Jakarta. 2012

Ramsey, G, Nurse, medical errors, and

culture of blame. Proquest

HealthManagement. 2 (25), 25-

27.[serialonline].http://proquest.

umi.com/pq dweb/. (12 April

2013).

Vena Jaladara, dkk. Hubungan tingkat

pengetahuan dan praktik perawat

mengenai keselamatan pasien

(patient safety) di instalasi gawat

darurat rs x semarang.Jurnal

kesehatan masyarakat (eJournal) Volume 3,

Nomor 1,

Januari 2015 (ISSN: 2356-3346)

http://ejournals1.undip.ac.id/ind

ex.php/jkm

Syarianingsih Syam, nur. Implementasi

Budaya Keselamatan Pasien oleh 
Perawat di Rumah Sakit Ibnu

Sina Makasar. Kes Mas: Jurnal

Fakultas Kesehatan Masyarakat,

Universitas Ahmad Dahlan,

Yogyakarta, IndonesiaVolume

11, Issue 2, September 2017, pp.

$169 \sim 174$ ISSN: $1978-0575$

Sri yulia,dkk. Peran perawat terhadap

pelayanan keselamatan pasien.

Jurnal Indonesia, vol 15, no 3,

November hal 2012; hal 185-

192.

Simamora, R. H. “ Buku Aajar

keselamatan pasien melalui

timbang terima pasien berbasis

komunikasi efektif:

SBAR.."(2018).

Tri Herawat, Yennike. Budaya

Keselamatan Pasien Di Ruang

Rawat Inap Rumah Sakit X

Kabupaten Jember, Jurnal

IKESMA Volume 11 Nomor 1
Potter, P. A., \& Perry, A. G., (2010).

Fundamental of nursing. Buku

1, edisi 7. Jakarta : Salemba

Medika.

Potter, P. A., \& Perry, A. G., (2013).

Fundamentals of nursing. (8th

ed). Elsevier 